\author{
Jaroskaw PaWkowski* \\ Uniwersytet Mikołaja Kopernika w Toruniu
}

\title{
DERIVATIVES AS SECURITY AGAINST MARKET RISK ON THE EXAMPLE OF THE SELECTED COMPANIES
}

Keywords: derivative, risk, hedging.

J E L Classification: G32.

Abstract: Company operating in current economic conditions are exposed to a series of different kinds of risk. In order to secure against some of them, firms may apply hedging, i.e. use of derivative instruments. This paper focus on the problem of using derivatives for the needs of reducing market risk, based on the example of KGHM Polska Miedź SA and PGNiG SA.

\section{INSTRUMENTY POCHODNE JAKO ZABEZPIECZENIE PRZED RYZYKIEM RYNKOWYM NA PRZYKEADZIE WYBRANYCH SPÓŁEK}

Słowa kluczowe: instrument pochodny, ryzyko, hedging. Klasyfikacja J E L: G32.

Abstrakt: Przedsiębiorstwa funkcjonujące w obecnych warunkach gospodarczych są narażone na szereg różnych rodzajów ryzyka. W celu zabezpieczenia się przed niektórymi z nich mogą stosować hedging, czyli wykorzystanie instrumentów pochodnych. W niniejszej pracy podjęto właśnie problematykę wykorzystania instrumentów pochodnych na potrzeby ograniczania ryzyka rynkowego na przykładzie KGHM Polska Miedź SA oraz PGNiG SA.

Translated by Jarosław Pawłowski

Data wpłynięcia: 05.12.2013; data zaakceptowania: 19.12.2013.

* Dane kontaktowe: jarek86@doktorant.umk.pl, ul. Broniewskiego 59B/27, 87-100 Toruń, tel. 511749195. 


\section{INTRODUCTION}

Risk is a basic economic phenomenon present in contemporary systems of market economy. It indispensably accompanies operation of the functioning entities. In current conditions of globalization, liberalization of capital flows and growing competition, its meaning is increasing. What is more, a catalogue of its identified types is expanding as well. In such realities, risk management in companies takes special meaning. For the purpose of securing against negative consequences of risk, derivative instruments are becoming applied more widely. Regarding validity of this problem, and its meaning, aim of this article is to present the application of derivatives for the need of market risk management, based on the example of selected Polish enterprises.

\section{RESEARCH METHODOLOGY AND THE COURSE OF THE RESEARCH PROCESS}

Choice of the subjects was dictated by their special exposure to a serious of its various kinds. For the purpose of realization of the agreed aim, there will be the following research methods used: descriptive, comparative, analysis of subject literature and case study.

\section{NOTION AND TYPES OF RISK}

Origin of the term 'risk' is ascribed to an Italian word riscare, which means to dare, to venture. There are two approaches that aim at explaining this key notion presented in literature of the subject. In the first one, risk is treated as uncertainty towards a future event (Drake, Fabozzi 2010, 185). When it comes to this work, the second approach differentiating categories of risk and uncertainty will be applied. The notion of risk refers to a situation, when only its future result is unknown, but it is possible to identify this result's alternatives, together with probability that they will appear. In turn, the term uncertainty determines a state, where there is no opportunity to conceptualize neither all variants of a given action nor the chances that it will take place (Dziawgo 1997, 14; Wachowiak 2006, 249).

The accepted way of looking on the notion of risk determines a wide array of its all kinds. Depending on the criteria that are followed, there is a series of 
classifications regarding separate types of risk. One of the basic division is that differentiating (Dubisz, Olejniczak 2003, 113):

- Semantic risk, caused by influence of powers that do not depend on a single entity, therefore it is not under this entity's control. Examples of this risk's sources encompass changes of, among others, interest rate, currency, inflation, legal and tax regulations, political and economic situation (Tarczyński 2003, 143-144).

- Specific risk, whose presence refers to individual decisions made by the entities. Therefore, it is controlled by separate subjects. Its causes lay in such fields as: company management, capital structure shaping, competition policy, availability of resources, liquidity, etc.

Companies that function in present market economic system, and operating an international business enterprise are exposed to a series of various types of risk. Scope of their presence and power of influence are conditioned by a specificity of the operated business and its scale. Scheme no 1 demonstrates the main kinds of risk that accompany operation of contemporary enterprises.

Scheme 1. Types of risk in a company

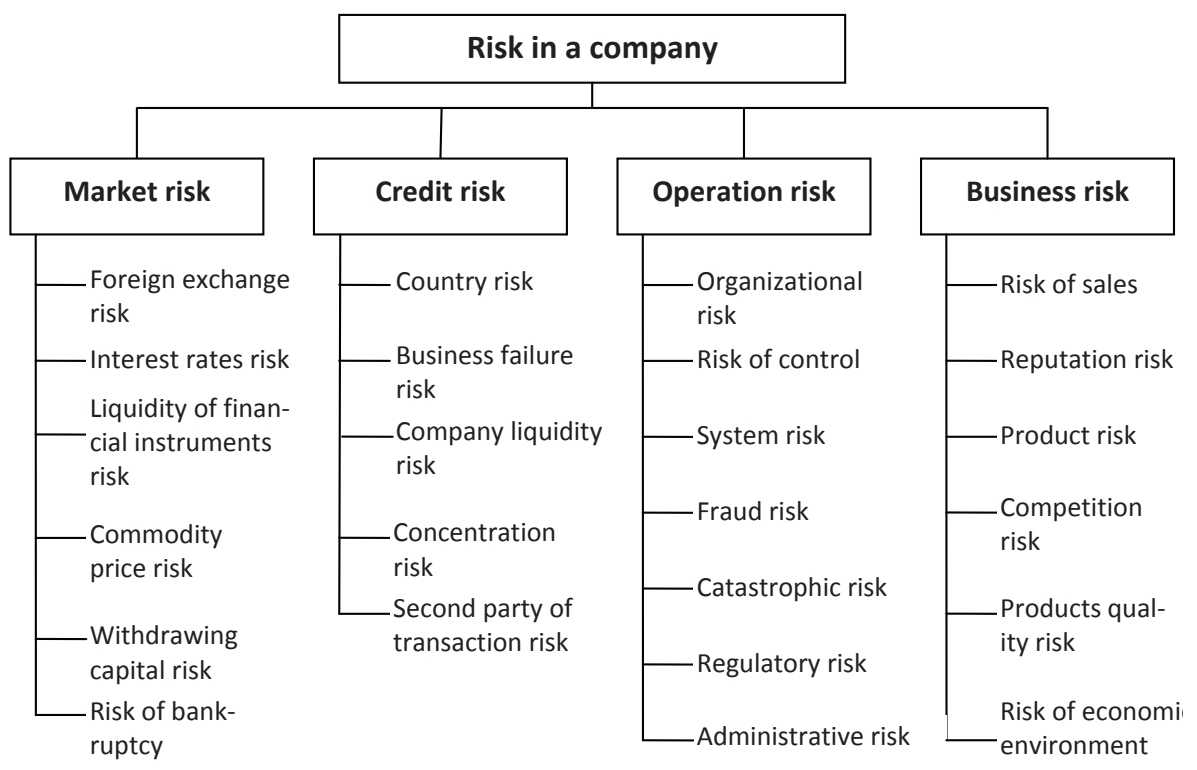

S o u r c e : Tarczyński W. (2003), 149. 
Specificity of risk makes it impossible to become eliminated in the course of the operated business (Głuchowski et al. 2001,11). However, there is a possibility to secure against some types of risk. For that purpose, it is necessary to start with its identification and measurement. Afterwards, within the framework of financial control of risk, one may independently manage the risk or transfer it to another entity. Basic methods of transferring risk embrace insurance and hedging. The essence of hedging includes use of derivative instruments in order to limiting a certain type of risk. It is achieved via a forward transaction referring to a given basic item, in a way that enables mutual compensation of their value. Thanks to this procedure, decreases in value of the protected item are compensated with profits from the derivatives and the other way round (Dziawgo 2010, 54-60; Mishkin 2004, 309; Nowaczyk 2006, 229).

\section{ChaRACTERISTIC OF DERIVATIVES}

Derivative instrument is some kind of a financial instrument, which price depends on value of another asset, instrument or parameter, that it was issued for, and which is called an underlying instrument (Hull 2009, 1; Durbin 2011, 3).

Intensive development of derivative instruments market have led to a situation that currently there are plenty of their types. Within their differentiated catalogue, there is a series of classifications conducted. The chosen ones are demonstrated on scheme 2 .

According to the theory developed by C. Smithson, regarding financial construction block, forward contracts and option rights constitute two elementary categories of derivative instruments. This is cause by the character of rights encompassed in those instruments. On their basis, within various combinations, it is possible to construct other kind of derivatives (Nieborak 2004, 73; Levinson 2006; 199). 
Scheme 2. Different kinds of derivatives

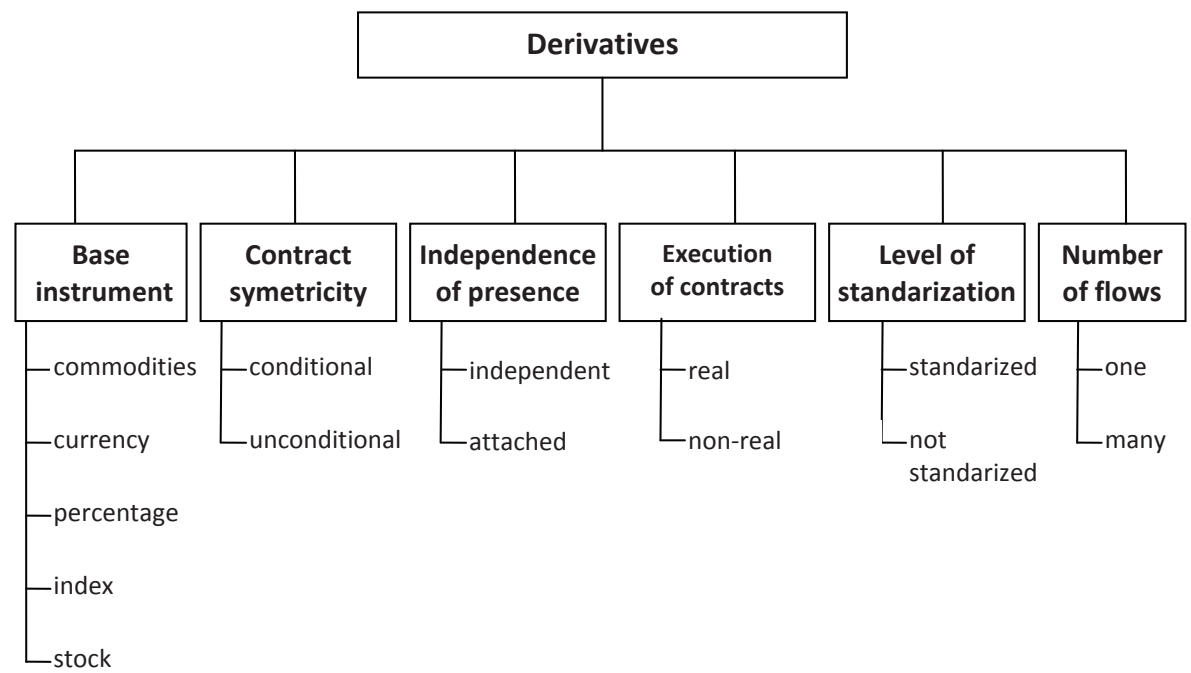

S o u r c e : Żebruń A. (2010), 22.

An essential division of derivative instruments is that differentiating their following groups (Dziawgo 2004, 162; Parameswaran 2011, 16; Mastalerz 2006, 19):

- forward contracts,

- futures contracts,

- options,

- swap transactions.

Forward contracts constitute agreements that determine emergence an obligation of one party to deliver, and of the second party to accept a given quantity of a base instrument, with an agreed price and at a specified date. Their conditions are not standardized, but determined individually between the interested parties. That's is why, forward contracts cannot be a subject of trade on the exchange market. Their settlement takes place through a physical delivery of the contract's subject or via a financial payment. Hence, those are real transactions (Dębski 2007, 318; Dziawgo 2007, 164-165).

Futures contracts are to a high extent similar to forward transactions. Differences first of all refer to a way of determining terms of the agreement, its form and date of settlement. Futures contracts are standardized, which means that the bear specific terms, and their settlement takes place in a financial 
form, which applies a non-real character to them. According to that, they compose a subject of trade within the market. Their close-up may emerge in any day of its functioning, through opening a contradictory position and payment of the difference between the current and contractual price of execution (Dziawgo 2007, 165-167).

Options constitutes another group of derivative instruments. This term is applied to determine agreements between two parties, which award one with a right to purchase (call option) or sell (put option) of an agreed quantity of the base instrument, at a specified price and at a future date. In turn, issuer of the option takes and obligation to execute it on its owner's request. For taking in this responsibility, the issuer obtains an option premium (Walmsley 1998, 137; Veale 2001, 247).

Essence of swap transactions encompasses the parties becoming obliged to exchange future payments according to strictly determined terms. Regarding subject of the swap, there are their two basic kinds (Pastusiak 2010, 277-28 3; Drake, Fabozzi 2010, 378):

- interest rate swap, exchange of payments with various interest rates, more precisely, of the arising interests. When subject of transactions is constituted by payments with changeable interest rate, then we have a basis swap. If the transaction regards flows with changeable and constant interest rate, then we have a cupon swap.

- currency swap, exchange of payments expressed in various currencies,

- commodity swap, exchange of payments, whose size is shaped according to the value of given commodities, which bear a physical form.

It needs to be emphasized that in recent years, the sector of derivative instruments have developed intensively. It is made visible in both increase of volume of transactions with its part, as well as a catalogue of their kinds functioning within trade.

In order to secure the enterprise against various types of risk, basis kinds of derivative instruments are often applied. However, regarding diverse needs in numerous entities, these are those complex strategies, constituting combinations of different derivatives that are applied. On one hand, their applications may arise from the need of lowering the costs of security. On the other, it may be cause by a strive to simultaneous security against various types of risks. 
Scheme 3. A pyramid of innovations referring to basic derivatives

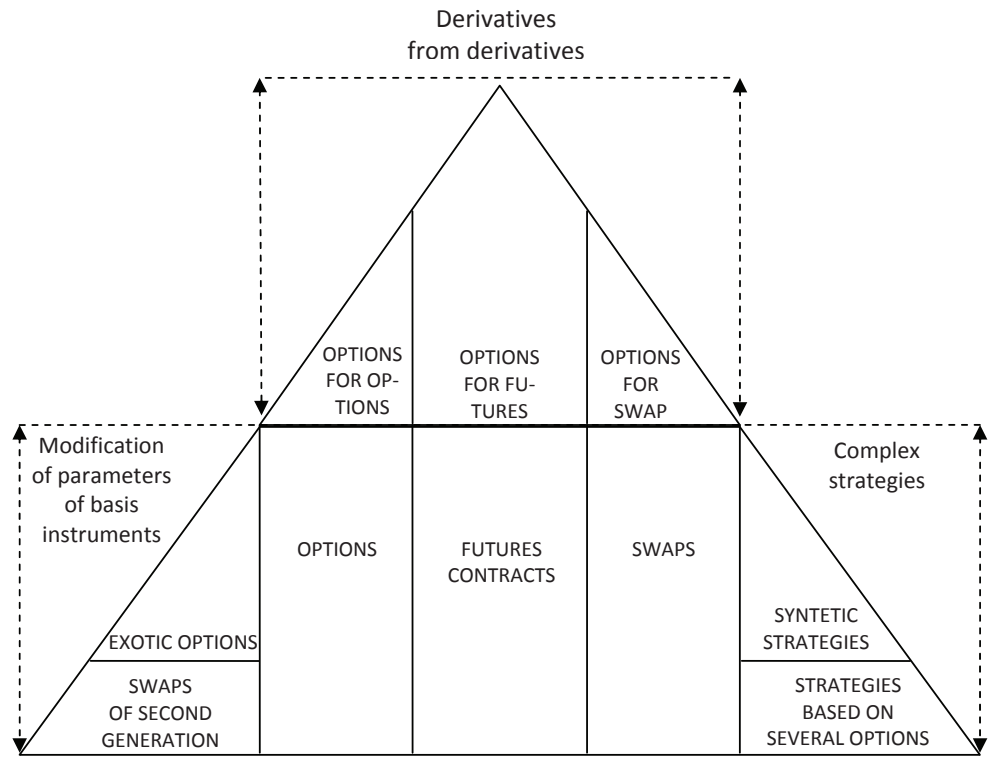

S o u r c e : Żebruń A. (2010), 22.

\section{HEDGING STRATEGIES ON THE EXAMPLE oF KGHM POLSKA MIEDŹ SA AND PGNiG SA}

Practical presentation of the using derivatives for the need of securing against chosen types of risks, was drawn up based on the example of enterprises that operate in Poland. The selection was conducted on the basis of a list encompassing 500 biggest Polish companies from 2012, prepared by "Polityka" weekly magazine. The initial analysis of reports from several biggest entities, according to the ranking through the prism of the included information regarding hedging, allowed to point KGHM Polska Miedź SA and PGNiG SA as interesting examples of the discussed problems (Lista 500 Polityki 2013).

KGHM SA first of all deals with exploring, proceeding and selling copper and silver. Character of the operated business causes that activity of the company is exposed to the following types of market risk (financial statement of KGHM SA for 2012, 84):

- metal price risk,

- foreign exchange risk, 
- interest rate risk,

- price risk connected with investments in debt securities and share units in open-end investment funds,

- price risk connected with investments in shares of public companies.

Specificity of resources and metals markets, including copper and silver, causes that they are characterized with a high level of price changeability. This is a source for the meaning of price risk in the discussed case. According to the fact that contracts regarding sales of copper and silver are concluded with prices expressed in American dollars, so foreign exchange risk is also crucial. In turn, the present risk of interest rates refers first of all to evaluation of the taken credits, loans, and issued or obtained debt financial instruments.

Application of derivative instruments was planned for scope of the company's process of financial risk management regarding price, exchange rate or interest rate risk. In 2012, we observed application of derivative instruments for the need of limiting price and exchange rate risk. In case of the interest rate risk it was agreed that it did not have significant influence on the results of the subject. In turn, tables 1, 2 and 3 illustrate planned hedging strategies for 2013 in KGHM Polska Miedź SA.

Table 1. Option strategies that refer to securing sales prices of copper, planned for 2013 by KGHM Polska Miedź SA

\begin{tabular}{|c|c|c|c|c|c|c|}
\hline \multirow[b]{2}{*}{ Period } & \multirow[b]{2}{*}{ Instrument } & \multirow[b]{2}{*}{ Volume [tons] } & \multicolumn{3}{|c|}{ Execution price of the option [USD/t] } & \multirow{2}{*}{$\begin{array}{c}\text { Effective price } \\
\text { of security } \\
\text { [USD/t] }\end{array}$} \\
\hline & & & $\begin{array}{c}\text { Sales of call } \\
\text { options }\end{array}$ & $\begin{array}{l}\text { Purchase of } \\
\text { put options }\end{array}$ & $\begin{array}{l}\text { Sales of put } \\
\text { options }\end{array}$ & \\
\hline 1st half 2013 & $\begin{array}{l}\text { Mewa } \\
\text { Korytarz } \\
\text { Korytarz } \\
\text { Mewa } \\
\text { Mewa } \\
\text { Korytarz } \\
\text { Korytarz }\end{array}$ & $\begin{array}{r}19500 \\
10500 \\
10500 \\
6000 \\
15000 \\
3000 \\
9000\end{array}$ & $\begin{array}{r}9500 \\
12000 \\
11500 \\
10200 \\
10300 \\
9200 \\
9300\end{array}$ & $\begin{array}{l}7200 \\
8500 \\
8200 \\
7700 \\
7800 \\
7200 \\
7300\end{array}$ & $\begin{array}{c}4700 \\
- \\
- \\
4500 \\
4500 \\
- \\
-\end{array}$ & $\begin{array}{l}6817 \\
8040 \\
7867 \\
7368 \\
7432 \\
6880 \\
6960\end{array}$ \\
\hline \multirow[t]{2}{*}{ 2nd half 2013} & $\begin{array}{l}\text { Korytarz } \\
\text { Korytarz } \\
\text { Mewa } \\
\text { Mewa } \\
\text { Korytarz }\end{array}$ & $\begin{array}{r}10500 \\
10500 \\
6000 \\
15000 \\
19500\end{array}$ & $\begin{array}{r}12000 \\
11500 \\
10200 \\
10300 \\
9300\end{array}$ & $\begin{array}{l}8500 \\
8200 \\
7700 \\
7800 \\
7600\end{array}$ & $\begin{array}{c}- \\
- \\
4500 \\
4500 \\
-\end{array}$ & $\begin{array}{l}8040 \\
7867 \\
7368 \\
7432 \\
7310\end{array}$ \\
\hline & SUMA & 135000 & & & & \\
\hline
\end{tabular}

S o u r c e : financial statement of KGHM Polska Miedź SA for 2012, 87. 
Table 2. Option strategies that refer to securing sales prices of silver, planned for 2013 by KGHM Polska Miedź SA

\begin{tabular}{|c|l|c|c|c|c|c|}
\hline \hline \multirow{2}{*}{ Period } & \multirow{2}{*}{ Instrument } & \multirow{2}{*}{$\begin{array}{c}\text { Volume } \\
\text { [mln ounces] }\end{array}$} & $\begin{array}{c}\text { Execution price of the option [USD/t] } \\
\text { Sales of call } \\
\text { options }\end{array}$ & $\begin{array}{c}\text { Purchase of } \\
\text { put options }\end{array}$ & $\begin{array}{c}\text { Sales of put } \\
\text { options }\end{array}$ & $\begin{array}{c}\text { Ef sective price } \\
\text { of security } \\
\text { [USD/t] }\end{array}$ \\
\hline \hline 1st half 2013 & Mewal & 1,80 & 65,00 & 40,00 & 20,00 & 38,02 \\
\hline 2nd half 2013 & Korytarz & 1,80 & 65,00 & 40,00 & 20,00 & 38,02 \\
\hline & SUMA & 3,60 & & & & \\
\hline
\end{tabular}

S o u r c e : financial statement of KGHM Polska Miedź SA for 2012, 87.

Table 3. Option strategies that refer to securing exchange rates, planned for 2013 by KGHM Polska Miedź SA

\begin{tabular}{|c|l|c|c|c|c|c|}
\hline \hline \multirow{2}{*}{ Period } & Instrument & $\begin{array}{c}\text { Denomination } \\
\text { [mIn USD] }\end{array}$ & \multicolumn{2}{|c|}{$\begin{array}{c}\text { Execution price of the option [USD/PL] } \\
\text { Sales of call } \\
\text { options }\end{array}$} & $\begin{array}{c}\text { Purchase of } \\
\text { put options }\end{array}$ & $\begin{array}{c}\text { Sales of put } \\
\text { course } \\
\text { of securitions } \\
\text { [USD/PLN] }\end{array}$ \\
\hline \hline 1st half 2013 & Mewa & 240 & 4,0000 & 3,1500 & 2,6000 & 3,1168 \\
& Korytarz & 240 & 4,2000 & 3,2000 & - & 3,1350 \\
\hline 2nd half 2013 & Mewa & 240 & 4,0000 & 3,1500 & 2,6000 & 3,1270 \\
& Korytarz & 240 & 4,2000 & 3,2000 & - & 3,1350 \\
\hline
\end{tabular}

S o u r c e : financial statement of KGHM Polska Miedź SA for 2012, 88.

Security against both price and exchange rate risk in the examined company is based on two option strategies. One of them is a strategy determined as "Mewa". It secures against risk of price/exchange rate falling below a determined minimum level, and at the same time it allows to take advantage from the growth to the maximum value accepted in the strategy. What is more, in case when market rate exceeds a so called participation rate, then the company obtains a subsidy. Construction of this strategy is based on (Strategia Mewa dla eksportera 2013):

- purchasing put options with a price/exchange rate of execution that is equal to minimum value,

- selling put options with a price/exchange rate of execution that is equal to maximum value, 
- purchasing call options with a price/exchange rate of execution that is equal to participation value.

This is a zero cost strategy. Hence, realization levels are determined in a way enabling equalization of paid and obtained bonuses, at the same time maintaining the desired security parameters. All options included within this strategy needs to be characterized by identical denomination and expiration date (Strategia Mewa dla eksportera 2013).

The second option strategy applied by KGHM SA is strategy "Korytarz". It encompasses (Strategia Korytarz dla eksportera 2013):

- purchasing put options with a price/exchange rate of execution that is equal to minimum value,

- selling calll options with a price/exchange rate of execution that is equal to maximum value.

This strategy allows to secure against risk of price/exchange rate decrease below the determined minimal value, and at the same time it provides an opportunity to make advantage from the increase to the agreed maximum value. By assumption, this is a zero cost strategy, which is why it requires proper selection of parameters (Strategia Korytarz dla eksportera 2013).

A second example of an enterprise that applies derivatives for the purpose of securing against market risk is Polskie Górnictwo Naftowe i Gazownictwo SA. Subject of operation of this company is searching and exploring ground gas and crude oil, as well as import, storage, sales and distribution of gas and liquid fuels. Hence, the company is especially exposed to the following types of market risks: (Financial statement of PGNiG 2012, 72)

- foreign exchange (currency) risk,

- interest rate risk,

- commodity price risk.

Exchange rate risk in case of PGNiG SA refers mainly to long-standing obligations, which were made in foreign currencies (Norwegian krone and euro). In order to secure against this kind of risk and connected with these obligations interest rate risk, the unit uses CCIRS transactions (Cross Currency Interest Rate Swap). Moreover, forward contracts, options and option strategies are adjusted to the needs of security against changeability of currency exchange rates. Character of business causes that the analysed company concludes futures contracts for gas deliveries. Therefore, a significant role in its operation is played by price risk, caused by fluctuations in petroleum products on fuel markets. A role of security in this kind of risk is played by Asian call options of European 
type, and risk reversal option strategies, which are based on purchasing both call and put options. This options are issued for the following indexes: Gasoil 0,1\% and FuelOil 1\% Barges FOB Rotterdam (Platt's). Table 4 presents chosen securities applied within the scope of market risk management strategy in PGNiG SA. (Financial statement of PGNiG SA for 2012, 85-86).

Table 4. Selected derivatives applied within the scope of hedging, in reference to market risk in PGNiG SA

\begin{tabular}{|c|c|c|c|c|}
\hline $\begin{array}{c}\text { Securing } \\
\text { instrument }\end{array}$ & $\begin{array}{l}\text { Secured } \\
\text { instrument }\end{array}$ & $\begin{array}{c}\text { Face value } \\
\text { in currency }[\mathrm{m} / \mathrm{n}]\end{array}$ & $\begin{array}{l}\text { Price of instrument } \\
\text { realization }\end{array}$ & Risk \\
\hline $\mathrm{CCIRS}^{1}$ & $\begin{array}{l}\text { Loan } \\
\text { Loan } \\
\text { Eurobonds } \\
\text { Loan }\end{array}$ & $\begin{array}{c}5244 \text { NOK } \\
481 \text { NOK } \\
500 \text { EUR } \\
4560 \text { NOK }\end{array}$ & $\begin{array}{l}0,5198 \\
0,5684 \\
4,1580 \\
0,5147\end{array}$ & $\begin{array}{l}\text { Currency and interest } \\
\text { rate risk }\end{array}$ \\
\hline 'Forward & Payments for gas & $\begin{array}{c}27 \text { EUR } \\
34 \text { EUR } \\
150 \text { USD } \\
210 \text { USD }\end{array}$ & $\begin{array}{l}4,1665 \\
4,1739 \\
3,3414 \\
3,2690\end{array}$ & Currency risk \\
\hline Call options & Payments for gas & $\begin{array}{l}290 \text { USD } \\
117 \text { USD } \\
390 \text { USD } \\
310 \text { USD }\end{array}$ & $\begin{array}{l}3,4839 \\
4,2670 \\
3,3775 \\
3,5328\end{array}$ & Currency risk \\
\hline Put options & Payments for gas & 20 USD & 3,003 & Currency risk \\
\hline $\begin{array}{l}\text { Commodity call } \\
\text { options }\end{array}$ & Payments for gas & $\begin{array}{c}0,503 \mathrm{HFO}^{2} \\
0,416 \mathrm{HFO} \\
0,373 \mathrm{GO}^{3} \\
0,338 \mathrm{GO}\end{array}$ & $\begin{array}{r}791,65 \\
732,38 \\
1097,37 \\
1014,05\end{array}$ & Price risk of gas \\
\hline $\begin{array}{l}\text { Commodity put } \\
\text { options }\end{array}$ & Payments for gas & $\begin{array}{c}0,454 \mathrm{HFO} \\
0,373 \mathrm{GO}\end{array}$ & $\begin{array}{l}594,79 \\
858,16\end{array}$ & Price risk of gas \\
\hline
\end{tabular}

1 Cross Currency Interest Rate Swap.

2 Heavy Fuel Oil.

3 Gasoil.

S o u r c e : financial statement of PGNiG SA for 2012, 86-87.

\section{ConCLUSIONS}

The conducted analysis of financial statements of KGHM and PGNiG in the context of ways of securing against market risk, implies that derivative instruments are basic tools applied for this purpose. They are usually used with regard to a single type of risk. However, there are some instruments, which may at the same time constitute a security against more than one kind of risk. Such 
an instrument was cross currency interest rate swap, used by PGNiG, which was a security against currency risk and interest rate risk.

A dominating type of derivative instruments, used by the examined companies, are options and strategies based on options. In case of PGNiG, some positions that are endangered with currency risk and interest rate risk are also secured through forward contracts and swaps. In case of KGHM company, all hedging strategies are based on options. It seems that the observed popularity of options arises out of their specificity, which enables to create zero cost strategies providing an expected level of execution prices. Experiences of the analysed companies prove that the derivatives may pose an effective security of results of operation against adverse influence of separate types of market risk. In KGHM company, there are actions, predicted for future several years, directed at increasing the share of the secured positions. However, despite this, the essence of derivatives causes that they are highly dangerous tools of financial engineering. Recent years have proved that if applied in a wrong way, they may cause significant financial loses, or even bankruptcies. Therefore, it is necessary to apply them for the needs of security with conscious, responsibility and knowledge. Companies should not engage those tools for speculative purposes.

\section{BIBLIOGRAPHY}

Dębski W. (2007), Rynek finansowy i jego mechanizmy, WN PWN, Warszawa.

Dubisz J., Olejniczak Z. (2003), Rynek finansowy. Efektywność, wycena, ryzyko, Wyd. Wyższej Szkoły Zarządzania i Marketingu w Lesznie, Leszno.

Durbin M. (2011), All about derivatives, McGraw-Hill, New York.

Dziawgo D. (1997), Credit-rating. Ryzyko i obligacje na międzynarodowym rynku finansowym, WN PWN, Warszawa.

Dziawgo D. (2007), Rynek finansowy. Istota - Instrumenty - Funkcjonowanie, SKwP, Warszawa.

Dziawgo D. (2010), Credit-rating na międzynarodowym rynku finansowym, PWE, Warszawa.

Fabozzi F. J., Drake P. P. (2010), The Basics of Finance. An Introduction to Financial Markets, Business Finance, and Portfolio Management, John Wiley \& Sons, Hoboken.

Głuchowski J., Huterski R., Jaaskelainen V., Nielsen A. P. (2001), Zarządzanie finansami w korporacjach międzynarodowych, Wyd. Uniwersytetu Mikołaja Kopernika, Torun.

Hull J. (2009), Options, futures and other derivatives, Pearson Education Inc, New Jersey. Jednostkowe sprawozdanie finansowe KGHM Polska Miedź SA za 2012 r.

Jednostkowe sprawozdanie finansowe PGNiG SA za 2012 r. 
Levinson M. (2006), Guide to financial markets, The Economist in association with Profile Books, London.

Lista 500 Polityki (2012), http://www.lista500.polityka.pl/rankings/show (access: 28.11.2013 r.).

Masztalerz M. (2006), Ewidencja i wycena bilansowa instrumentów finansowych, „Prawo Przedsiębiorcy", 36 (712).

Mishkin F. S. (2004), The economics of money, banking and financial markets, Pearson Addison Wesley, New York.

Nieborak T. (2004), Pochodne instrumenty finansowe, Wyd. Difin, Warszawa.

Nowaczyk T. (2006), Hybrydowe instrumenty finansowe jako narzędzie zarzq̨dzania ryzykiem w przedsiębiorstwie, [w:] Finanse przedsiębiorstwa, P. Kapuś (red.), Wyd. Uniwersytetu Marii Curie-Skłodowskiej, Lublin.

Parameswaran S. (2011), Fundamentals of financial instruments. An introduction to Stocks, Bonds, Foreign Exchange, and Derivatives, John Wiley \& Sons, Hoboken.

Pastusiak R. (2010), Przedsiębiorstwo na rynku kapitałowym, Wyd. CeDeWu, Warszawa.

Strategia Korytarz dla eksportera (2013), http://www.bzwbk.pl/przedsiebiorstwa-i-korporacje/produkty-skarbu/zarzadzanie-ryzykiem-walutowym/strategie-opcyjne/korytarz-eksporter/strategia-korytarz-dla-eksportera.html (access: 30.11.2013 r.).

Strategia Mewa dla eksportera (2013), http://www.bzwbk.pl/przedsiebiorstwa-i-korporacje/produkty-skarbu/zarzadzanie-ryzykiem-walutowym/strategie-opcyjne/ mewa-eksporter/strategia-mewa-dla-eksportera.html (access: 30.11.2013 r.).

Tarczyński W. (2003), Instrumenty pochodne na rynku kapitałowym, PWE, Warszawa.

Veale R. S. (2001), Stocks, bonds, options, futures, New York Institute of Finance, New York.

Wachowiak P. (2006), Proces decyzyjny, [w:] Funkcjonowanie przedsiębiorstwa w gospodarce rynkowej, P. Wachowiak (red.), SKwP, Warszawa.

Walmsley J. (1998), New financial instruments, John Wiley \& Sons, Inc., USA.

Żebruń A. (2010), Instrumenty pochodne zabezpieczające w rachunkowości, Wyd. Difin, Warszawa. 
